\title{
The Employment Cluster of Omnibus Law: Embodiment the Concept of Nachtwakerstaat or Welfarestate?
}

\section{Anak Agung Gede Duwira Hadi Santosa', Kadek Agus Sudiarawan² I Made Marta Wijaya ${ }^{3}$}

\author{
${ }^{1}$ Faculty of Law, Universitas Udayana, Indonesia, E-mail: agung_santosa@unud.ac.id \\ ${ }^{2}$ Faculty of Law, Universitas Udayana, Indonesia, E-mail: \\ agus_sudiarawan@unud.ac.id \\ ${ }^{3} R A H$ (The House of Legal Experts) Law Office, Indonesia, E-mail: \\ martawijaya97@gmail.com
}

Submitted: October 3, 2020; Reviewed: November 10, 2020; Accepted: December 5, 2020

\begin{tabular}{ll}
\hline \multicolumn{1}{c}{ Article Info } & \multicolumn{1}{c}{ Abstract } \\
\hline Keywords: & The presence of the omnibus law of the Employment \\
Omnibus Law, Employment & Cluster of Job Creation Law haven't consider to \\
Cluster, Welfarestate, & solve the crucial problems in the Manpower Law, \\
Nachtwakerstaat & but its further away from the purpose of the \\
Dolfarestate concept and leads to the purpose of the & nachtwakerstaat. The aims of this research to \\
10.25041/fiatjustisia.v15no2.2219 & determine position omnibus law of the Job Creation \\
& Law after it's passed within in the scope of \\
welfarestate concept or nachtwakerstaat concept & and to analyse the construction of labour law \\
concept in accordance to concept of welfarestate in \\
the future. This research used a normative legal \\
research method with a statute approach and \\
elaborated with a legal concept analysis approach. \\
The results show there are crucial problems in the \\
Employment Cluster of the Job Creation Law such \\
as the elimination of several principal provisions in \\
Manpower Law that indicates the role and presence \\
of the state in labour law is getting minimum and \\
also the Job Creation Lawpoint out many things that \\
returned the agreement mechanism by the parties. \\
This show that, Employment Cluster of the Job \\
Creation Law tends to the nachtwakerstaat concept \\
and far away from welfarestat concept. The \\
solutions of the issues by doingrevision to the \\
Employment Chapter of the Job Creation Law by \\
adjusted the welfarestate concept, alsorestore and \\
strengthen the function of the government as a part \\
of industrial relations as a regulator and supervisor.
\end{tabular}




\section{A. Introduction}

The preamble to the 1945 Constitution of the Republic of Indonesia (hereinafter referred to as the 1945 Constitution of the Republic of Indonesia) has firmly stated that the formation of the Unitary State of the Republic of Indonesia is to create a just, affluent, and prosperous and safe social order both physically and mentally. Within these objectives, in the 1945 Constitution of the Republic of Indonesia states that "every citizen has the right to work and a decent living for humanity." 1 Based on these provisions, the state has an obligation to fulfill the rights of these citizens with all efforts through any policy making by the government. Hopefully every policy by government will always be able to fulfill the rights of citizens to obtain decent work and livelihoods for all Indonesian people. ${ }^{2}$ To fulfill the right to work and a decent living for all people, is a basic and important aspects of national development in Indonesia. The steps that have been taken by the government to fulfill the rights of citizens by striving created and expanded job opportunities, in order to reduce the high unemployment rate and be able to absorb the workforce maximally. ${ }^{3}$ In addition, these efforts also aim to encourage productive of workforce to be more active and optimistic in developing the cooperative business sector and Micro, Small and Medium Enterprises (hereinafter referred to as MSMEs). ${ }^{4}$ This is very important to optimize this ideas in order to improve the condition of the national economy to be improving the welfare of the Indonesian people.

Nonetheless, there still problems that ultimately led to delays in national development, especially in field of economy such as in investment, employment and the environment sectors. Finally, the government made efforts to overcome that problems by issuing legal products inform of regulations whose contained the solutions to obstacles experienced through the formation of omnibus law of the Job Creation Law. ${ }^{5}$ The Job Creation Law was ratified on October $5^{\text {th }}, 2020$ in the plenary session of the Indonesian Parliament and was signed by the President on November $2^{\text {nd }}, 2020$ which

\footnotetext{
${ }^{1}$ Article 27 Paragraph (3) the 1945 Constitution of the Republic of Indonesia.

${ }^{2}$ Ismiatun, and Bunyamin Alamsyah, "Perlindungan Hukum Terhadap Pekerja Rumah Tangga Menurut Peraturan Menteri Ketenagakerjaan Nomor 2 Tahun 2015 Dalam Perspektif Hukum Positif Hukum Indonesia," Legalitas: Jurnal Hukum 9, no.1 (2019): 113-142, DOI: 10.33087/legalitas.v9i1.144.

${ }^{3}$ Susmiyati, Haris Retno, and Erna Susanti, "Implementasi Kewajiban Mempekerjakan Tenaga Kerja Lokal Pada Perusahaan Pertambangan Batubara Di Kabupaten Berau Kalimantan Timur," Risalah Hukum 15, no. 1 (2019): 11-31.

${ }^{4}$ Indika, Miki, and Yayuk Marliza. "Upaya Upaya Pemberdayaan Usaha Mikro Kecil Menengah (UMKM) Dalam Mengatasi Kemiskinan di Kecamatan Tugumulyo Kabupaten Musi Rawas." Journal Management, Business, and Accounting 18, no. 3 (2019): 49-66, DOI: 10.33557/mbia.v18i3.598.

${ }^{5}$ https://www.dpr.go.id/berita/detail/id/30590/t/UU+Ciptaker+Hadir+Untuk+Indonesia+lebih +Maju, accessed on December 29, 2020.
} 
later became Law Number 11 of 2020 concerning Job Creation (hereinafter referred to as the omnibus law of the Job Creation Law). ${ }^{6}$ This law was a Government-initiated bill that submitted on February $13^{\text {th }}, 2020$ by the Government to the House Representative Council of the Republic of Indonesia (DPR RI). This law made by the aims to absorb many workers as can as possible through streamlining regulations on several fields in Indonesia, so it has hampered national economic development. ${ }^{7}$ The Job Creation Law, in technically formulation the law used the omnibus law model that covered 10 (ten) fields, which are improving the investment ecosystem and business activities, employment, convenience, protection, empowerment of cooperatives and UMKM, ease of doing business, support for research and innovation, land acquisition, economic zones, central government investment and acceleration of national strategic projects, implementation of government administration, and imposition of sanctions. ${ }^{8}$

As the purpose of made these regulations with the omnibus law technique, according to the President, is to overcome regulatory problems that are currently constraining Indonesia. It is very important to take regulatory reform steps in shorten period, by simplifying, cutting and trimming the number of regulations in Indonesia, especially those regulation related to the economy sectors. ${ }^{9}$ That was a breakthrough step for the government in overcoming the hyper regulation that occurs todays. Because, on several policies that have been taken previously such as tightening regulatory proposals including Ministerial/Institutional Regulations. Several things that should be done when formulated the law were reviewing the draft regulation before it's promulgated, evaluating the validity of the regulation and conducting mediation in the event of a dispute or conflict of norms in several regulations. ${ }^{10}$ However, these efforts didn't produce maximum results to reduce the number of regulations, in which as one of the obstacles to national economic growth due to the lack of investors investing in Indonesia due to the

\footnotetext{
${ }^{6}$ https://apple.co/3hXWJOLhttps://nasional.kompas.com/read/2020/11/03/00085091/uu-ciptakerja-resmi-dinomori-jadi-uu-nomor-11-tahun-2020, accessed on December 29, 2020.

${ }^{7}$ https://apple.co/3hXWJ0Lhttps://money.kompas.com/read/2020/10/06/132341526/diusulkan -jokowi-ini-perjalanan-panjang-keluarnya-uu-cipta-kerja?page=all, accessed on December 30, 2020.

${ }^{8}$ Prabowo, Adhi Setyo, Andhika Nugraha Triputra, and Yoyok Junaidi, "Politik Hukum Omnibus Law di Indonesia," Pamator Journal 13, no. 1 (2020): 1-6. DOI: 10.21107/pamator.v13i1.6923.

${ }^{9}$ Yhannu Setyawan, "Rancangan Undang-Undang Omnibus Law Cipta Kerja Dalam Perspektif Undang-Undang Nomor 12 Tahun 2011 Tentang Pembentukan Peraturan PerundangUndangan," Jurnal Ilmiah Hukum dan Keadilan 7, no. 1 (2020): 150-164.

${ }^{10}$ Ima Mayasari, "Kebijakan Reformasi Regulasi Melalui Implementasi Omnibus Law Di Indonesia," Jurnal Rechts Vinding: Media Pembinaan Hukum Nasional 9, no. 1 (2020): 1-15, DOI: 10.33331/rechtsvinding.v9i1.401.
} 
complexity of the rules that must be met. ${ }^{11}$ However, the omnibus law policy is not necessary accepted by the public, especially legal experts. Because of due to several substantial and procedural matters were not fulfill the appropriate legislation process when drafted the omnibus law on the Job Creation Law.

It is necessary to know that every formulation and formation should be appropriate legislation process (beginslen van behoorlijke regelving) in accordance with the applicable provisions based on 3 (three) foundations, namely the appropriate philosophical, juridical, and sociological foundations. ${ }^{12}$ Also, it is important to understand how the existence of each rule that contained in the omnibus law, because of each rule in omnibus law regulating different content and different subject (adressat)..$^{13}$ Therefore, if the drafting process of laws and regulations does not meet these requirements, it may become a reason for rejection like what happened to omnibus law on the Job Creation. . For those who refuse, to argue that the existence of the omnibus law of the Job Creation Law is based on several reasons, such as the omnibus law technique is not know in the technique of forming legislation in Indonesia, the substance contained is very detrimental to the citizens' rights,, threatens the sustainability of the environment, and create negative impact in several sectors of life. ${ }^{14}$ One of the cluster substances in the Job Creation Law received a lot of rejection is the employment cluster. It is because of this cluster very clear show how strong the economic approach was used. From the perspective of laws and regulations by using a cost-benefit approach based on the theory of economic analysis on law (economic analysis of law) maybe one reason that make legal experts reject this regulation. ${ }^{15}$ According to the theory of economic analysis on law that stated the quality of law in a country will be judged by the extent of the law be able to achieve efficiency. ${ }^{16}$ This means the law is not assessed based on its ability to provide justice and social benefits to the community, but by resulting a shift of protection that leads the use of a risk-based approach. This is viewed as counterproductive with aspects

\footnotetext{
${ }^{11}$ https://jeo.kompas.com/naskah-lengkap-pidato-presiden-joko-widodo-dalam-pelantikanperiode-2019-2024, accessed on December 23, 2020.

12 https://www-beta.kompas.id/baca/opini/2020/01/04/omnibus-law-uu-sapu-jagat/, accessed on January 3, 2021.

${ }^{13}$ Ibid.

14 Bayu Dwi Anggono, "Omnibus Law Sebagai Teknik Pembentukan Undang-Undang: Peluang Adopsi Dan Tantangannya Dalam Sistem Perundang-Undangan Indonesia," Jurnal RechtsVinding 9, no. 1 (2020): 17-37.

15 Muhamad Azhar, "Omnibus Law sebagai Solusi Hiperregulasi Menuju Sonkronisasi Peraturan Per-Undang-undangan di Indonesia," Administrative Law and Governance Journal 2, no. 1 (2019): 170-178, DOI: 10.14710/alj.v2i1.170-178.

${ }^{16}$ Romli Atmasasmita, Analisis Ekonomi Mikro Tentang Hukum Pidana Indonesia (Jakarta: Prenada Media, 2017), 4.
} 
of labor law protection which should be the main substance in the omnibus law of the employment cluster of the Job Creation Law.

Whereas the legal protection aspect in employment law contains permanent employment law politics as referred to the values of Pancasila, the 1945 Constitution of the Republic of Indonesia, and customary law that has existed since the beginning of independence. ${ }^{17}$ This basis has a purpose to be implemented in the context of developing Indonesia's human resources in order to create a prosperous society, a just, and affluent both safe materially and spiritually. ${ }^{18}$ This is in line with the concept of a welfarestate as stated by the Republic of Indonesia in the fourth paragraph of the Preamble of the 1945 Constitution of the Republic of Indonesia. ${ }^{19}$ Whereas, the aim of the Indonesian state that in line with welfare-state concept, is to realize the general welfare by organizing the state power to control administration and politics. Also, to modify the market for general welfare and the economic capacity of its society. ${ }^{20}$ The manifestation state's responsibility within the framework of the welfarestate, by regulate and provide legal certainty, justice and benefit to the society. ${ }^{21}$ However, this isn't manifested in the omnibus law of the Job Creation Law that has been ratified and promulgated in the state gazette.

Pursuant to that, it can be implying the omnibus law of the Job Creation Law has deviated far from the philosophical foundation of the Indonesian nation, which in the end the presence of this regulation was unable to solve the crucial problems in Law Number 13 of 2003 concerning Manpower (hereinafter referred to as the Manpower Law) which existed all this time. The omnibus law of the Job Creation Law is seen as creating new problems that have a negative impact on worker protection. And then became a form of far deviation from the mandate of the state's purpose, to create social welfare accordance with the welfarestate concept that adopted by Indonesia to date.

Based on the explanation above, it is important to re-examine whether the omnibus law position of the Job Creation Law, is it on the welfarestate concept or its return to the nachtwakerstaat concept after the enactment of the regulation? And it's important to find solutions related to how employment laws should be compatible in line with the welfarestate concept in the future? Based on this, it's important to conduct the position of the welfarestate

\footnotetext{
17 Arifuddin Muda Harahap, "Analisis Undang-undang Nomor 13 Tahun 2003 Tentang Ketenagakerjaan Di Tinjau dalam Kajian Politik Hukum," Jurnal Penelitian Medan Agama 10, no. 2 (2019): 281-297.

${ }^{18} \mathrm{Ibid}, 284$.

19 Ahmad Hunaeni Zulkarnaen, "Masalah Rawan Dalam Hubungan Industrial Dan Konsep Negara Kesejahteraan Indonesia," Jurnal Hukum Mimbar Justitia 2, no. 2 (2018): 806-825, DOI: $10.35194 /$ jhmj.v2i2.32.

${ }^{20}$ Ibid.

${ }^{21}$ Agus Darmawan, "Politik Hukum Omnibus Law Dalam Konteks Pembangunan Ekonomi Indonesia." Indonesian Journal of Law and Policy Studies 1, no. 1 (2020): 13-24, DOI: 10.31000/ijlp.v1i1.2655.
} 
concept adopted in the employment cluster after the enactment of the Job Creation Law.

In the preparation of this scientific article which refers to the results of research, research methods are used which are fundamental in essence meaningful to provide guidance in studying, analyzing, and understanding the law in question. In other words, knowledge is obtained through research with the scientific method. The research method used in this research is the legal research method with the type of legal research, namely legal research, that the type of research which discusses and analyzes at the level of norms, principles and legal doctrines. ${ }^{22}$ The types of approaches used to support normative legal research are the statutory approach and legal concept analysis. The statutory approach is applied by examining all legal products ranging from laws to regulations that are relevant to the legal issues discussed. This research focuses on the legal arguments built in the study of existing legal regulations, namely the Job Creation Law and the Manpower Law. Meanwhile, the legal concept analysis approach is used to study the Job Creation Law in the perspective of the welfarestate theory or the nachtwakerstaat theory. Document research techniques are applied in this journal as a technique of tracing legal materials with qualitative analysis as a study /research analysis.

\section{B. Discussion}

\section{Position of Employment Cluster on Omnibus Law: Welfarestate or Night Watch State}

Before determining where the position of the Omnibus law of the Job Creation Law, especially the employment cluster, with a comprehensive study, it's important to understand two types of countries based on the state purpose. There are 3 (three) types of countries based on their known objectives, namely, the type of policy state (Polizie Staat), the type of nachtwakerstaat(Nacht Wacker Staat) and the type of welfarestate (Walfare staat or Social Service State). ${ }^{23}$ In this research, only 2 (two) types will be discussed, which the nachtwakerstaat type and the welfarestate type. And it will later become a reference in determining the type of country purpose was adopted and become the basic reference in formulating the omnibus law of the Job Creation Law by the Indonesian government.

The nachtwakerstaat type is the type of state whose job is to maintain order and security only. The state is prohibited from interfering in the private

\footnotetext{
${ }^{22}$ Abdulkadir Muhammad, Hukum dan Penelitian Hukum (Bandung: Citra Aditya Bakti, 2014), 52.

${ }^{23}$ I Dewa Gede Atmadja, Ilmu Negara Sejarah, Konsep dan Kajian Kenegaraan (Malang: Setara Press, 2012), 63.
} 
affairs of the people. ${ }^{24}$ This type also called the state of night patrol. The nachtwakerstaat in this views, the state only has a negative task, only taking care of the police, justice, collecting various taxes and foreign policy. ${ }^{25}$ The state must not fulfill positive social tasks, such as providing assistance (caring for the poor society especially in the field of charity). ${ }^{26}$ The nachtwakerstaat,was originally develop related to the liberal theory of the household which is related to, among other things, liberal economic theory; the way to healthy social and economic harmony passes through "concurrency (free competition)" and "advancing one's own interests." 27 The nachtwachterstaat has a similarity with the formal law state concept. In principle, the formal rule of law emphasizes the interests of individualism based on the interests of the aristocracy, so that a state with the concept of a formal law state has a very narrow and passive role. Even more extreme action, the state only maintains the safety of the property of the aristocrats, protects against theft, fraud, breach of contracts and security disturbances. But doesn't have rights to monopolize, impose or regulate relations between citizens. So, it's not surprising that the form of the country is based on a liberalism system, and consequently in results was social inequality and injustice in the economy will also emerge. ${ }^{28}$ Therefore, the role of the state is very minimal, so it is often said to be a minimum state or monarchism.

In other words, the government prioritizes the laissez faire approach in creating welfare. The laissez faire approach is refers to an economic system wherein the government takes a "hands-off" approach to transactions by and between private parties. The idea is that, in such an economic system, free enterprise will regulate itself, as if one party offers a product that is of low quality, people won't buy it. Examples of laissez-faire transactions that the government leaves alone include regulations, tariffs, subsidies, and privileges. ${ }^{29}$ It can conclude that the laissez faire approach is a system of government or other leadership that takes a "hands off" approach to issues and

\footnotetext{
${ }^{24}$ Abdul Halim Barkatullah, "The Dialectics of Freedom of Contract Doctrine With WelfareState Concept In Providing Legal Protection to Consumers," PalArch's Journal of Archaeology of Egypt/Egyptology 17, no. 6 (2020): 7248-7262.

${ }^{25}$ Ibnu Sina, and Syaiful Bakhri, Chandranegara, "The Role of Political Ideology on Devolution of State Objectives," Tarumanagara Law Review 1, no. 1 (2019): 024-046, DOI: 10.24912/tlrev.v0i0.3055.

${ }^{26}$ Mr. N. E.Algra et.al, Mula Hukum, Cetakan Pertama (Jakarta: Binacipta, 1983), 171.

${ }^{27}$ Ibid.

28 Venatius Hadiyono, "Indonesia dalam Menjawab Konsep Negara Welfarestate dan Tantangannya," Jurnal Hukum, Politik dan Kekuasaan 1, no. 1 (2020): 23-33, DOI: 10.24167/jhpk.v1i1.2672.

${ }^{29}$ Alan Bogg, "'Individualism'and 'Collectivism'in Collective Labour Law," Industrial Law Journal 46, no. 1 (2017): 72-108, DOI: 10.1093/indlaw/dww045.
} 
transactions between private parties. In return, the market mechanism gets a large portion of meeting people's needs. ${ }^{30}$

Along with the passage of time and the development of human life, this type of nachtwakerstaat has also developed into a formal law state.According to F.J. Stahl, there are 4 (four) elements of a formal legal state, namely, the recognition of human rights, the separation of powers between the legislative, executive and judicial powers, according to the trias politica theory, the government must be based on the principle of legality or on the basis of law, and the existence of "Administrative Courts" which adjudicate any administrative disputes between the authorities and residents. ${ }^{31}$ The subsequent development of a formal legal state gave birth to a material law state or a substantive law state, there are differences, namely the actions of the state and its apparatus are not only based on laws such as formal law states, but also based on unwritten legal laws. ${ }^{32}$ This means, the state can take action outside the law as long as it's deemed important and urgent to follow up on an emergency policy. Provided the action can be justified according to the law. ${ }^{33}$

The development after the existence the material law state type, namely the type of welfarestate type. Basic aspects from welfarestate type was born when the "Reform Act" was issued in 1832 in England. ${ }^{34}$ Vilhelm Aubert stated that the welfarestate type refers to certain rights of citizens and to the ability of the state to meet the demands that flow from these rights. ${ }^{35}$ According to Spicker, the welfarestate that is practiced by modern countries nowadays, in many ways, based on social protection patterns that have previously been developed through collective social action. ${ }^{36}$ The notion of a welfarestate type was born in the late 19th century as a reaction to the weaknesses of classical liberalism and capitalism and at the same time a reaction to the teachings of the "nachtwakerstaat" which idealized the principle of "the best government is that which orders as little as possible (the best government is the least government)." 37 The term "welfarestate" generally refers to a number of aspects of a political regime that intends to provide security in relation from negative consequences of modernization, equality in relation to the realization of the civil, political and social rights of

\footnotetext{
${ }^{30} \mathrm{Ibid}$.

${ }^{31}$ Hadiyono, Venatius, Loc.Cit.

32 Zulkarnain Ridlwan, "Negara Hukum Indonesia Kebalikan Nachtwachterstaat," FIAT JUSTISIA: Jurnal Ilmu Hukum 5, no. 2 (2014): 141-152.

${ }^{33}$ Ibid.

${ }^{34}$ Atmadja, I Dewa Gede, op.cit, h. 65.

35 I Dewa Gede Palguna, Walfare State Vs Globalisasi Gagasan Negara Kesejahteraan Di Indonesia (Depok: Rajawali Press, 2017), 17.

${ }^{36} \mathrm{Ibid}, 19$.

${ }^{37} \mathrm{Ibid}, 20$.
} 
individuals, and justice. In relation to the distribution of welfare, which is generated collectively. In this regard, it's also said that welfarestate type is the state and its equipment or apparatus serving the interests, welfare and welfare of the community, including providing social security, such as health services, and insurance for the care of the poor and neglected children. ${ }^{38}$ One example of this type of state is where in a country there are public agencies, namely state enterprises that regulate the welfare of the people, for example by the presence of a state companies.

The type of welfarestate is seen as a revolutionary process without through power action that causes the instability of the country. ${ }^{39}$ This change emerged as the pouring out of people's aspirations about the importance of strengthening the idea that a welfarestate is a noble ideal that every modern country in the world wants to achieve, including Indonesia. According to Mustamin Daeng Matutu's doctrine, which states that the basic principles of a modern welfarestate are always related to aspects of the public or collective interest and also the interests of each individual in accordance with their nature and reality. ${ }^{40}$ Furthermore, according to Mustamin Daeng Matutu, every human entity as God's creation has the right to material welfare, such as proper food, clothing and shelter needs..$^{41}$ Not only that, the type of welfarestate also requires the use of natural resources that are scientifically based and managed, solely to improve the standard of living of the people. ${ }^{42}$

In addition, the type of welfarestate also mandates the state c.q. government to be able regulate as well as supervise the implementation of the rights and obligations of every legal subject in everyday life. This is because, in the type of welfarestate concept advice the state as a tool formed by humans to achieve common goals, prosperity and social justice for all the people of the country. It can be said the type of welfarestate is a state and its accessories that devote themselves to the public interest in order to be able to realize the prosperity and welfare of the community. One of them is by guaranteeing the fulfillment of the basic rights of every citizen such as the right to feel safe, the right to be free from discrimination, freedom from slavery, guaranteed rights to health, education and social security. ${ }^{43}$ Not limited in the regime of public or private law, these rights must be fulfilled considering that often in the realm of private law these basic rights are reduced or not fulfilled at all. ${ }^{44}$

\footnotetext{
38 I Dewa Gede Atmadja, Op.Cit, 67.

39 Ibid., 66.

${ }^{40}$ Ibid.

41 Ibid.

${ }^{42}$ Ibid, h66-67.

43 Ayunita Nur Rohanawati, "Jaminan Sosial Tenaga Kerja di Indonesia Sebagai Negara Kesejahteraan Ditinjau Dari Perspektif Hukum Progresif," Jurnal Ilmu Hukum Justitia Et Pax 32, no. 1 (2016): 17-31, DOI: 10.24002/jep.v32i1.759.

${ }^{44}$ Ibid., 23.
} 
This often occurs in employment agreements that give a disadvantage to the one party with a lower position (subordinate position) like workers/laborers. Therefore, in the context of realizing the concept of a welfarestate, it's important for the state c.q. the government to ensure any policies taken didn't go out from the basic corridors of the type of welfarestate that adopted by Indonesia. Because of that, there is a sharp difference between the type of nachtwakerstaat and welfarestate. One of that differences becomes a reference in determining the position of the omnibus law of the Job Creation Law is the extent to which the state can intervene the private sphere of each citizen, specifically in the employment cluster after the omnibus law of the Job Creation Law was promulgated.

Indonesia as a welfarestate as stated in the fourth paragraph of the Preamble of the 1945 Constitution of the Republic of Indonesia, states that apart from having the duty to organize government, it's also obliged to carry out general welfare. ${ }^{45}$ As the obligation to carry out general welfare, the state through authorized government entities is justified in interfering or intervening in strategic areas of life, one of that is field of manpower. The welfarestate concept, give a justification for interference with legal policies on employment regulation. It has an impact to a shift in employment law or classical labor law. ${ }^{46}$ Whereas, the initial labor law or currently known as the employment law regime, has experienced a shift from being only the realm of civil law or private law.This shift is the basis for a paradigm shift in the aspect of industrial relations.

Industrial relations are a relationships system that formed between actors in the process of producing goods and /or services, which consists of elements that are workers/laborers, entrepreneurs, and the government. ${ }^{47}$ Industrial relations in Indonesia basically pursuant to values of Pancasila and the 1945 Constitution of the Republic of Indonesia. Industrial relations was established not only to provide legal protection to workers/laborers, but also to create welfare for all Indonesian people by the law. ${ }^{48}$ The regulation expected to be able to realize the welfare of employers/entrepreneurs, workers/laborers and the welfare of the general society. . This system built in the true form to open and expand employment opportunities, maintain, increase job security and maintain, increase existing income for the short period. And for the long-term aims of that system to increase the income of the Indonesian people. ${ }^{49}$

\footnotetext{
${ }^{45}$ Ahmad Hunaeni I Zulkarnaen, Op.Cit., 807.

${ }^{46} \mathrm{Ibid}, 807-808$.

${ }^{47}$ Zulkarnaen, Ahmad Hunaeni."Perlindungan Hukum Terhadap Pekerja Dalam Pelaksanaan Hubungan Industrial." Padjadjaran Journal of Law 3, no. 2, 2016: 407-427, DOI: 10.22304/pjih.v3n2.a10.

48 Ibid.

${ }^{49}$ Ibid.
} 
The idea was stated when the legislators and the government passed Law Number 13 of 2003 concerning Manpower (hereinafter referred to the Manpower Law) as a concrete step to guarantee the protection of workers/laborers. Also, to improve the quality of the workforce and their participation in development and increase the protection of workers/laborers and their families in accordance with human dignity. ${ }^{50}$ As well as to guarantee the basic rights of workers/laborers to reach the equal opportunity and treatment without discrimination to realize appropriate welfare of workers/laborers and their families. However, the objectives in the Manpower Law are based on the welfarestate concept as the ideals of the Indonesian state law diminished and even disappeared after the government and the House of Representative passed the omnibus law on the Job Creation Law. So, it needs to be criticized regarding the concept of state type that adopted when amended the Manpower Law through the omnibus law technique in the Job Creation Law.

The Duhaime Law Dictionary defines omnibus law as "a draft law before a legislature which contains more than one substantive matter, or several minor matters which have been combined into one bill, ostensibly for the sake of convenience." ${ }^{51}$ The difference between drafting and forming technique in the ordinary law to the technique of the omnibus law, it can be seen in terms of the substance or content in the regulations. First, the ordinary laws only contains certain substances and/or subjects, whereas in the omnibus law contains many different substances and/or subjects and it's generally not related to one another. ${ }^{52}$ Second, seen from the technique of its formation, the ordinary laws undergo changes or \revoked usually carried out to use one of methods, whether to change or revoke the previous regulation in one proposal..$^{53}$ The omnibus law used changing, revoking, or enforcing technique on several provisions in various laws with only one proposal for the formation of laws to parliament. ${ }^{54}$ Third, the concept of ordinary law in Indonesia known for codification of laws and this concept is very different from the meaning of the omnibus law. Codification of law is legal bookkeeping in a set of laws in the same materials. ${ }^{55}$ Omnibus law is called as a broom-sweep law because contains with a lot of substances and/or subject matter.

\footnotetext{
${ }^{50}$ S. Charda, "Karakteristik Undang-Undang Ketenagakerjaan Dalam Perlindungan Hukum Terhadap Tenaga Kerja." Jurnal Wawasan Yuridika 32, no. 1 (2015): 1-21, DOI: 10.25072/jwy.v32i1.86.

${ }^{51} \mathrm{http}: / /$ www.duhaime.org/LegalDicnionary/0/OmnibusBill.aspx, accessed on December 28, 2020.

52 Rizal Irvan Amin, "Omnibus Law Antara Desiderata Dan Realita," Jurnal Hukum Samudra Keadilan 15, no. 2 (2020): 190-209, DOI: 10.33059/jhsk.v15i2.2729.

${ }^{53}$ Ibid., 194.

${ }^{54}$ Ibid.

${ }^{55}$ Ibid.
} 
Those 3 (three) differences as the reasons why many parties reject the presence of the Omnibus law of the Job Creation Law especially in employment cluster. It's already received a lot of attention from the workers/laborers, because it's considered detrimental the workers/laborers and too siding the employers/entrepreneurs. As well as the government seems to be independent of the function of regulating and supervising the implementation of industrial relations, which has been happening and ignoring the welfarestate concept that clearly stated in the Preamble of the 1945 Constitution of the Republic of Indonesia.

The employment cluster is one of the crucial parts that has been received a lot of criticism after amended through the omnibus law of the Job Creation Law. This is quite reasonable because many good substances in the Manpower Law were suddenly amended and deleted in the Job Creation Law. First, related to the provisions of the specified period of time working agreement (PKWT). In the Job Creation Law, this provision was abolished, whereas previously it was regulated in Article 59 of the Manpower Law. In the provisions of Article 59 paragraph (1) of the Manpower Law stipulates that PKWT only can be made for certain jobs which according to the type and nature or activity of the work, that will be completed within a certain time, namely in letter b it's stated that the work is estimated to be completed in not too long and a maximum of 3 (three) years. ${ }^{56}$ This article is amended in the Job Creation Law to become "a work agreement for a specified period of time only can be made for a certain job which according to the type and nature or activity of the work will be completed within a certain time, namely as follows: ${ }^{57}$

a. Once completed or temporary work;

b. Work which is estimated to be completed in the not too long time;

c. Seasonal work;

d. Work related to new products, new activities, or additional products which are still in trial or investigation; or

e. Work of which type and nature or activity are not permanent."

The amendment of Article 59 paragraph (1) letter b of the Manpower Law which removes the limitation provision for the category of "maximum time on 3 (three) years" correlates with the disappearance of the provisions of Article 59 paragraph (4) of the Manpower Law which regulates that "a certain time work agreement is based on a certain period of time can be held for a maximum of 2 (two) years and may only be extended 1 (one) time for a maximum period of 1 (one) year." In addition, the Job Creation Law also eliminates the provision that PKWT that has passed a maximum period of 2 years plus 1 year, legally changes to PKWTT (permanent work agreement).

\footnotetext{
${ }^{56}$ Article 59 paragraph (1) letter b Law Number 13 of 2003 on Employment

${ }^{57}$ Article 59 of Law Number 11 of 2020 on Job Creation
} 
The elimination of these provisions has serious implications for guaranteeing legal certainty for workers/laborers. The losses of this provisions make the maximum period and the limit for extension is tantamount to eliminating the opportunity for workers/laborers to become permanent workers/laborers who previously had the status of workers/laborers on a contract. When a worker/laborer still as the contract workers/laborers that's very prone to experiencing rights violations when compared to permanent workers/laborers. ${ }^{58}$ The amendment in the Job Creation Law as declared in Article 56 paragraph (3) states that "The period of completion of a certain job is determined based on the work agreement." It's means that this provision reduces and weakens the role of the state as regulator and supervisor in industrial relations, because they no longer intervene in the term of the PKWT after the Job Creation Law published.

The second problem in the Manpower Chapter in the Job Creation Law is the amended articles regarding to the wages of workers/laborers. There are several provisions that have amended regarding the wages, first, the loss of the phrase "the need for a decent life" which was previously in the Manpower Law as the consideration to determine the minimum wage. Policies in concerning to the wage aspects are basically inseparable from the state obligations c.q. government to ensure the fulfillment of people's rights to a decent life as mandated by Article 27 paragraph (3) of the 1945 Constitution of the Republic of Indonesia. ${ }^{59}$ It is very important to emphasize the provisions on the calculation minimum wage in the Job Creation Law no longer use the phrase "the need for a decent living" as an aspect of the calculation of the workers/laborers wage. In the Job Creation Law, the basis of calculation only pursuant to variable economic growth or inflation aspect. When examined carefully, the variables of economic growth or inflation aspect haven't been able to represent the needs of a decent living for workers/laborers because economic growth or inflation aspect were standardized nationally instead of referring the conditions in each region which differ from one another. It's very ironic when the government starts to distance the wage policy that has been mandated by the constitution to provide a decent living for humanity as the goals of the Indonesian state.

In the same case regarding wage policies, Article $88 \mathrm{C}$ paragraph (1) of the Job Creation Law states that "the Governor is obliged to set the provincial minimum wage." Furthermore, in paragraph (2) it is stated that "the Governor can determine the district/city minimum wage with certain conditions." This means that the Job Creation Law only provides the obligation to determine the

\footnotetext{
${ }^{58}$ Amin, Rizal Irvan, Op.Cit., 288.

59 Susani Triwahyuningsih, "Perlindungan dan Penegakan Hak Asasi Manusia (HAM) di Indonesia," Legal Standing: Jurnal Ilmu Hukum 2, no. 2 (2018): 113-121, DOI: 10.24269/ls.v2i2.1242.
} 
minimum wage at the provincial level, while at the district/city level it is choice or optional due to used word "can" in the provisions of Article 88C paragraph (2) of the Job Creation Law. In addition, the Job Creation Law also eliminated the sectoral minimum wage provisions without any clearly and logically arguments. In fact, as known the sectoral minimum wage has been considered more representative because it represents conditions in certain sectors in several regions that have contributed greatly to the country's economy. ${ }^{60}$

Not only the Job Creation Law eliminated, but also reduced the scope of wage policy in Article 88 paragraph (3) of the Job Creation Law. Whereas the types of wage policies currently only cover: 1) Minimum wages; 2) Wage structure and scale; 3 ) overtime pay; 4) Wages for not working and / or not doing work for certain reasons; 5) Form and method of payment of wages; 6) Items that can be calculated with wages; and 7) Wages as the basis for calculating or paying other rights and obligations. ${ }^{61}$ It's not enough juts reduces the types of wage policies on the Job Creation Law, regulators also amended the structure and scale of wages that regulated in Manpower Law. The Job Creation Law amended Article 92 paragraph (1) of the Manpower Law: "Employers prepare the structure and scale of wages by taking into account class, position, years of service, education and competence." 62 And changed into "Entrepreneurs are required to arrange the structure and scale of wages in the company by taking the company's capabilities and productivity." ${ }^{33}$ This amended quite detrimental to workers/laborers because it eliminates considerations of classes, positions, years of services, educations, and also competences in structure and scale of the wages. In the fact, structure and scale of wages can be used as an effort a motivation to speed up the improvement of workers/laborers competences through awarding the wage increased. By eliminating this provision, which is actually a counterproductive step with the aspirations of improving the quality of human resources for workers/laborers in Indonesia.

Another provision should be criticized in the Job Creation Law about elimination provisions in Articles 64 and 65 in the Manpower Law. Whereas, Article 64 of the Manpower Law is the basis for outsourcing enforcement. The elimination of Articles 64 and 65 becomes odd, when Article 66 is not deleted. It should be more understood that in the Manpower Law the provisions on Article 64, up to Article 66 constitute as the complete unit and it must be

\footnotetext{
${ }^{60}$ Kadek Agus Sudiarawan, and Putu Ade Hariestha Martana, "Implikasi Hukum Pengaturan Upah Minimum Sektoral Kabupaten Badung terhadap Pelaku Usaha pada Sektor Kepariwisataan di Kabupaten Badung Provinsi Bali," Supremasi Hukum: Jurnal Penelitian Hukum 28, no. 1 (2019): 35-56, DOI: 10.33369/jsh.28.1.33-56.

${ }^{61}$ Article 88 paragraph (3) Law Number 11 of 2020 of Job Creation.

${ }^{62}$ Article 92 paragraph (1) Law Number 13 of 2003 on Employment.

${ }^{63}$ Article 81 point 30 Law Number 11 of 2020 of Job Creation
} 
viewed hole, not partially. By doing the elimination of Articles 64 and 65, but keep the Article 66 alive, it will have bad implications for legal certainty and will further confuse employers/entrepreneurs and workers/laborers that impacted to the situation on inventories Indonesia. Moreover, by eliminated the provisions of Article 64 and Article 65, the provisions regarding restrictions on the types of work that can be outsourced will be disappeared. Whereas in the past the Manpower Law had explicitly regulated restrictions on the types of outsourcing. Some of jobs type were not allowed to be carried out in type of central position in the company. If it's not limited, the outsourcing practice will increasingly happened that carried out by employers/entrepreneurs, even though the form of work relations using the outsourcing system or the triangular work relationship system tends to be more unfavorable for workers/laborers. ${ }^{64}$

Articles in the employment cluster of the Job Creation Law which also drew a lot of criticism and caused polemics to the existence of new regulations regarding the termination of employment (PHK). It is should to remember the concept of industrial relations in Indonesia applies the welfarestate concept based on the values of Pancasila and the 1945 Constitution of the Republic of Indonesia. Philosophically, layoffs on industrial relations related to the conception of Pancasila that apply in Indonesia were avoid as much as possible the layoffs by made very rigid and strict provision in order to prevent layoffs. ${ }^{65}$ It can be seen that the rigid layoff rules in the Article 151 paragraphs (2) and (3) of the Manpower Law. Whereas that two rules as form of protection for workers/laborers, so the employers/entrepreneurs do not layoffs workers/laborers unilaterally. According to this provision, every termination of employment is obliged to be negotiated by both parties. ${ }^{66}$ If there is no agreement reached, then the termination only can be taken after obtaining a decision from the industrial relations dispute settlement agency. ${ }^{67}$ The stipulation of the industrial relations dispute settlement institution embodies the presence of the state as one of the elements in industrial relations based on the Manpower Law. It's to ensure the dismissal acts by parties, either the workers/laborers or the employers/entrepreneurs. ${ }^{68}$ This is a form of embodiment of the concept of welfarestate that should be preserved, but this conception was changed drastically when the Job Creation Law passed.

Whereas Article 151 paragraph (2) of the Job Creation Law changes the provisions for termination of employment become "In the event that

\footnotetext{
${ }^{64}$ Nuradi, "Perlindungan Hukum Pekerja Alih Daya Dalam Pelaksanaan Hubungan Industrial Guna Mendukung Terwujudnya Iklim Investasi Yang Kondusif Bagi Tercapainya Kesejahteraan Pekerja," Pakuan Law Review 5, no. 1 (2019): 20-37, DOI: 10.33751/.v5i1.1184. ${ }^{65}$ Ahmad Hunaeni I Zulkarnaen, Op.Cit, 807-808.

${ }^{66}$ Article 151 paragraph (2) and (3) Law Number 13 of 2003 on Employment.

${ }^{67}$ Ibid.

${ }^{68}$ Ibid.
} 
termination of employment is unavoidable, the entrepreneur will notify the intention and reason for terminating employment to the workers/laborers and/or workers/laborers unions." ${ }^{99}$ Article 151 paragraph (2) of the Job Creation Law raises concerns regarding the possibility of unilateral dismissal, because dismissals only can be done through notification from the employers/entrepreneurs without having preceded by negotiation as stipulated in the Manpower Law. By seeing an employment relationship between a workers/laborer and an employer's/entrepreneur is always ideal by placing the workers/laborers and the employers/entrepreneurs in an equal position. In fact, the position of the workers/laborer is still subordinated to the employs/entrepreneurs, even though since 2003 the Manpower Law has been issued as an effort to equalize the position of the two parties through the presence of government as a part in industrial relations.

In fact, regulation on the provisions in Article 151 paragraph (2) of the Job Creation Law is a backwards step when there was an effort to protect and equalize the position of workers/laborers. The reality to do the rejecting layoffs and defending their rights is not an easy thing to do for workers/laborers. Inequality in bargaining position, fear of superiors, and ignorance of their rights as workers/laborers often make workers/laborers unable to do much to demand justice for layoffs.

Furthermore, the Job Creation Law also amended the provisions regarding severance pay and tenure awards that can be obtained by workers when a layoff occurs. In addition, the Job Creation Law also eliminates the obligation to replace housing as well as the treatment and cares for workers who have been laid off. ${ }^{70}$ It can be said the changed provisions regarding layoffs in the Job Creation Law declared that the existence of this law is very far away from the expectation of protection workers/laborers because in fact it makes layoffs easier when compared to the Manpower Law. Other matters that also need to be criticized are related to work relations such as the period of the contract and leave. It returned to the agreement by the parties through the work agreements, collective labor agreements, or company regulations. It will be appropriate if the bargaining position of the parties is equal, but the position of workers/laborers to the employers/entrepreneurs are not in the case. This clearly reduces protection for workers/laborers, because in an unequal relationship between workers/labor and employers/entrepreneurs.

The explanation above sufficient to state the employment chapter in the Job Creation Law was increasingly eliminating the role and presence of the state in exercising control over the rules of employment law. Whereas in philosophically, employment law in Indonesia was made to protect the interests of workers/laborers. Actually, protecting business interests can be

\footnotetext{
${ }^{69}$ Article 151 paragraph (2) Law Number 11 of 2020 on Job Creation.

${ }^{70}$ Article 156 paragraph (2) Law Number 11 of 2020 on Job Creation. .
} 
done by other legal instruments without compromising the protection of workers/laborers' rights and interests. For example, providing tax incentives, ensuring there is no corruption and extortion, and guaranteeing a simple and straightforward bureaucracy to employers/entrepreneurs. By doing partial revisions to the Manpower Law through the omnibus law technique on Job Creation Law does not delve into the philosophical-historical foundation and ultimately creates new problems and has very bad implications for the protection of workers/laborers in the future. The first problem is the government's participation has begun to diminish in industrial relations between workers/laborers and employers/entrepreneurs. In fact, the spirit that was built when forming the Manpower Law was to ensure the rights of workers/laborers were fulfilled and to provide an equal bargaining position between employers and workers with the government being present as the party presenting both positions. And this is very much in line to the concept of welfarestate by the presence of government on the industrial relations authorities the position of workers or laborers with employers not always subordinated. The existence of the Job Creation Law is a backward step for the government in realizing the state's purpose to create general welfare which is the principal value of welfarestate concept. And then, right now it has turned into a nachtwakerstaat, especially in the employment cluster due to the lack of government intervention on strategic matters and crucially part, in which ultimately harm workers/laborers in the future.

\section{The Concept of Employment Law Pursuant to Welfarestate Theory in The Future}

The purpose of the state in the concept of welfarestate is to improve the welfare of its people. This purpose to carried out by the organizing of power of state to control the administration and political direction of the state in order to modify the situation for social welfare and economic prosperity of the community through economic development efforts. ${ }^{71}$ In economic development, especially on investment development which is a manifestation of the state's responsibility within the framework of the welfarestate concept. The presence of the omnibus law regulation on the Job Creation Law as one of government steps to attract more investors who want to invest in Indonesia by given a simple and guaranteed mechanism, also the legal certainty. ${ }^{72}$ This is the purpose of the government to formulate the omnibus law of the Job Creation Law as a solution for overcome the low foreign investment that entered to Indonesia. As long as the policy is accordance to the welfarestate concept refers as an ideal model development that focuses on increasing welfare through giving an important and greater role to the state by providing

${ }^{71}$ Arifuddin Muda Harahap, Op.Cit, 282.

${ }^{72}$ Amin, Rizal Irvan, Op.Cit, 192. 
comprehensive social services to its citizens. ${ }^{73}$ Is this really embodied in the omnibus law of the Job Creation Law? The answer is not reflected the main objectives of the Welfarestate concept, are:

a. Controlling and utilizing socio-economic resources for the public interest;

b. Ensuring a fair and equitable distribution of wealth;

c. Reducing poverty;

d. Providing social insurance (education and health) for the poor;

e. Providing subsidies for basic social services for disadvantaged people;

f. Provide social protection for every citizen. ${ }^{74}$

Amendments to the employment chapter of the Job Creation Law haven't been able to fulfill those main objectives and unable to provide solutions for problems in the Manpower Law. It is important to reexamine how the concept of employment law in the future should be in accordance to welfarestate concept.

The construction of employment law in accordance to welfarestate concept that should be understood clearly in what meant by prosperity, in order to formulate an employment law politics that embodies the optimal type of welfarestate. Whereas according to Paul Spicker welfare is "... stands for developed ideal in which welfare is provided comprehensively by the state to the best possible standards." The meaning of welfare when seen the opinions of Midgley, Tracy, and Livermore and Thompson and Suharto that welfare can be seen from four meanings, namely:

a. As a condition of welfare (well-being)

A condition can be said to be a condition of prosperity when a community condition is in a safe and happy condition, that is, material and nonmaterial needs can be fulfilled as its basic needs.

b. As a Social Service

The social service as referred to is when in the country the social security provider can provide five forms of social services, including social security, health services, education, housing and personal social services. Countries that have embraced the concept of welfare and have organized this concept of welfare include Britain, Australia and New Zealand.

c. As a Social Benefits

The concept of welfare as a social benefit is particularly applicable in the United States, namely by providing benefits that prioritize giving to the poor. Because the main target recipients of this social security are the poor, disabled and unemployed.

d. As a Process or Planned Efforts

\footnotetext{
${ }^{73}$ Saut P Panjaitan, "Politik Pembangunan Hukum di Bidang Investasi Suatu Keniscayaan Konstitusi Ekonomi," Jurnal Konstitusi 7, no. 2 (2016): 047-066, DOI: 10.31078/jk\%25x.

${ }^{74}$ Ibid.
} 
Welfare in this concept is defined as improving the quality of life through the provision of social services and social benefits that can be provided by individuals, social institutions, the community, and government agencies. $^{75}$

Based on that opinions, it can be infer the welfare is a condition, process and right that must be fulfilled in order to achieve peace, tranquility and inner and outer happiness. Therefore, the welfarestate concept must become reference when formulate the important provisions of employment law in the future so that they can become a means of developing employment law.

Whereas according to Roscoe Pound, law as a tool of social engineering (law as a tool for social engineering) implies that law is one of the tools that can change the social conditions of society, including its welfare. ${ }^{76}$ Pound argues that law must be able to balance all interests in society, a diverse society and many different perspectives in responding to things in law. ${ }^{77}$ Legal reform must take into the interests of workers/laborers. Manpower law reform through omnibus law should pay attention to the welfare of workers/laborers, not the other way around. As is currently the case, there are still many workers/laborers who are still far from being worthy of their life. On that basis, it's important to create progressive legal breakthroughs in the development of the legal system in Indonesia. Whereas according to Satjipto Rahardjo, progressive law must appear in the legal system, law enforcers, and courts, that progressive law means the law should be able to keep up with the times, be able to respond and change the times with all its foundations, and be able to serve the community by being aware of its aspects and the morality of its human resources. ${ }^{78}$

The purpose of changes the employment law regime in the context of developing human resources in Indonesia as a whole will be able to create a prosperous, just, affluent, equitable society, both materially and spiritually based on Pancasila and the 1945 Constitution of the Republic of Indonesia. Whereas the ideal foundation of economic development in Indonesia refers to Article 33 paragraph (1) of the 1945 Constitution of the Republic of Indonesia which states that the Indonesian economy is structured as a joint effort based on the principle of kinship. ${ }^{79}$ The elucidation of Article 33 paragraph (1) of

\footnotetext{
${ }^{75}$ Ayunita Nur Rohanawati, Op.Cit., 22-23.

76 Theddy, "Pembaruan Hukum dalam Perlindungan Hukum terhadap Pekerja/Buruh di Indonesia dalam Mewujudkan Kesejahteraan," Warta Dharmawangsa 14, no. 3 (2020): 379381 .

${ }^{77}$ Ibid.

${ }^{78}$ Ibid., 376.

${ }^{79}$ Suyanto Edi Wibowo, "Memahami Makna Pasal 33 Undang-Undang Dasar Negara Republik Indonesia Tahun 1945 Perihal Penguasaan Oleh Negara Terhadap Sumber Daya Alam Comprehend the Meaning Of Article 33 Of The 1945 Constitution Of The Republic Of Indonesia On State Authority Over Natural Resources," Jurnal Legislasi Indonesia 12, no. 4 (2018): 1-57.
} 
the 1945 Constitution of the Republic of Indonesia states that the prosperity of community is prioritized, not the prosperity of an individual. ${ }^{80}$ Before the amendment was made, the cooperative was either in a position as the backbone of the national economy or as an integral part of the national economic order. ${ }^{81}$ It's important to then examine the politics of employment law before changes by omnibus law of the Job Creation Law.

Permanent employment law politics (referring to the results of the amendment four times to the 1945 Constitution of the Republic of Indonesia, Pancasila values and customs) have existed since the beginning of independence, but their implementation is influenced by the political constellations that exist in each government regime. ${ }^{82}$ Legal politics in the dimension of enforcement can encourage the formation of laws that have an elitist nuance, which is held for the purpose of supporting the ruling regime. ${ }^{83}$ Therefore, legal politics should be based on good intentions on basic policies and enactment policies in a rational and balanced manner, than the implementation of these regulations has not been able to accommodate the interests of all parties. ${ }^{84}$ Whereas Article 33 of the 1945 Constitution of the Republic of Indonesia contains moral and cultural messages as a constitution of the Republic of Indonesia. Article 33 of the 1945 Constitution of the Republic of Indonesia merely provides guidance on the composition of the economy and the state's authority to regulate economic activities, it reflects ideals, a belief that held firmly and consistently fought for by government leaders. ${ }^{85}$

The absence of equal legal position between workers/laborers and employers/entrepreneurs will result in injustice, distrust of each other, and will even lead to frequent employment disputes. So, it is important to regulate things that have not been resolved so far in the field of employment law. It is considered because it contains important matters and concerns public interest, it means that the government has transferred it from private law to public law. Another reason can cause employment problems, such as claims of rights disputes, claims of interests and claims of layoffs. For example, a case that goes to the Industrial Relations Court (PHI) concerns the use of foreign workers that every decision by the PHI judicial body will be an evaluation for the interests of the manpower sector. And that evaluation should be the basis for consideration when compiling the omnibus law academic manuscript of

\footnotetext{
${ }^{80}$ Ibid., 3 .

${ }^{81}$ Arifuddin Muda Harahap, Op.Cit., 283

82 Ibid.

${ }^{83}$ Ibid.

${ }^{84}$ Abbas Anwar, Bung Hatta dan Ekonomi Islam (Jakarta: Kompas Media Nusantara, 2010), 193.

${ }^{85}$ Wibowo, Suyanto Edi, Op.Cit, 4-5.
} 
the Job Creation Law in accordance with politics law which is also adopted by the Manpower Law.

Whereas political law or legal policy is a matter concerning laws that will be enforced either by making new laws or by replacing old laws, to achieve the goals of the state. ${ }^{86}$ According to Moh. Mahfud MD said that political law is a choice about laws to be enforced as well as choices about laws to be repealed or not enforced, all of which are intended to achieve the goals of the state as stated in the Preamble of the 1945 Constitution of the Republic of Indonesia. ${ }^{87}$ The Preamble of the 1945 Constitution of the Republic of Indonesia includes a view of life, legal awareness and ideals, moral ideals concerning individual independence, national independence, humanity, social justice, national peace, political ideals regarding the nature, form and purpose of the state, social life, religion; as an embodiment of human conscience, it has been refined and solidified to become the basis of the state Pancasila. ${ }^{88}$ Therefore, legal development policies play an important role in guaranteeing and protecting a just, prosperous, and prosperous community life. The direction and objectives in development of law must be focused and gradual strived towards the direction of goals state as envisioned. Likewise, the amendment to the 1945 Constitution of the Republic of Indonesia basically an effort to create a just and democratic society as contained in the fourth paragraph of Preamble of the 1945 Constitution of the Republic of Indonesia.

The development to observe the updating of government regulations regarding manpower from time to time is a manifestation of the government's commitment to continuously improve employment law. In order to fulfill a sense of justice for perpetrators or subjects in employment law in which there are entrepreneurs and workers/laborers. The rules in the labor law issued by the government with the principle aim to regulate the life of workers in Indonesia. It has been explicitly stated in Article 27 paragraph (2) of the 1945 Constitution of the Republic of Indonesia that; "Every citizen of the State has the right to work and a living that is decent for humanity." According to this article, there are two important things about the rights of every Indonesian citizen, that are the right to get a job and the right to obtain a decent living. ${ }^{89}$ A job does not only have economic value, but also must have a feasible value for humans. A new job fulfills such as the occupational safety and health as well as the welfare of the workers/laborer's life should be guaranteed in its

\footnotetext{
${ }^{86}$ Mia Kusuma Fitriana, "Peranan Politik Hukum dalam Pembentukan Peraturan PerundangUndangan di Indonesia sebagai Sarana Mewujudkan Tujuan Negara (Laws and Regulations In Indonesia As The Means Of Realizing The Country'S Goal)," Jurnal Legislasi Indonesia 12, no. 2 (2018): 1-27.

${ }^{87}$ Harahap, Arifuddin Muda, Op.Cit., 293.

${ }^{88}$ Ibid.

89 Alam, Syamsul, Mohammad Arif, "Perlindungan Hukum Terhadap Pekerja: Perspektif Tanggung Jawab Konstitusional Negara," Kalabbirang Law Journal 2, no. 2 (2020): 123-133.
} 
implementation. ${ }^{90}$ Thus, workers/laborers as Indonesian citizens need to get attention from the government, so they can actively participate in development.

Whatever is done in the law, one thing that should never ignore is the human aspect as a central part of the law, because the law is made for humans, not the others wise. ${ }^{91}$ Therefore, in every legal process in a country based on law, the human aspect must occupy in central position, including allowing humans to participate in the process that determines their destiny. According to that aims, the state in orderly comfortable be like a home of the Indonesian people come true just based on the law. ${ }^{92}$ Based on that, it's important to provide ideas in drafting employment laws in accordance welfarestate concepts, by repositioning the position of workers/laborers who are juridical free right now, but in social and economically are not free. It causes of the employer/entrepreneur who will determine the conditions of work and the worker/laborer only decide whether to accept or not. Given the lower position of the workers/laborers than the employers/entrepreneurs, it's necessary for government intervention to provide legal protection. Legal protection by government in the form of policies is quite a lot, as an effort to increase workers/laborers wages, followed by productivity and skills development of workers/laborers through national strategic programs.

Hopefully in the future workers/laborers could accept justice and welfare for their normative rights that guaranteed by the law. ${ }^{93}$ Thus, it is necessary to make changes to the Job Creation Law, especially the employment cluster by rearranging the principle matters in accordance to welfarestate concept, which is returning and strengthening government functions as one of the elements in industrial relations as a regulator and supervisor, repositioning the position. Give the workers/laborers same position as the employers/entrepreneurs both in juridically and sociologically. In addition, it is necessary to restore the basic rights of workers/laborers, such as wages in accordance to the consideration of the need for a decent life, guarantee the status of workers/laborers, guarantee other rights and receive appropriate rewards so that workers/laborers become more productive. For the government, especially the Ministry of Manpower, to be more optimal in carrying out its duties and authorities in supervising the implementation in field of industrial relations.

\footnotetext{
${ }^{90} \mathrm{I}$ bid.

${ }^{91}$ Agus Darmawan, Op.Cit., 18.

${ }^{92}$ Zulkainain Ibrahim,. "Pengaturan dan Penegakan Hukum Pengupahan dalam Sistem Hukum Ketenagakerjaan," Ius Quia Iustum Law Journal of Islamic University of Indonesia 22, no. 4 (2015): 652-673.

${ }^{93}$ Ibid.
} 


\section{Conclusion}

Generally, there are several crucial issues in the employment chapter of the Job Creation Law. First, the loss of the maximum time limit in the PKWT; second, the elimination of the phrase "decent living needs" as a reference for calculating the minimum wage; third, the shift in the paradigm of layoffs is made easier because the possibility of layoffs is opened up only through notification of employers to workers without prior negotiation; fourth, the removal of restrictions on outsourcing in work relations; and fifth, the Job Creation Law also greatly reduces state control over employment relationships, because many things are returned to the agreement mechanism of the parties. Therefore, the position of omnibus law of the Job Creation Law can be said to be no longer in accordance to welfarestate concept as the basis for the formation of the Manpower Law and is currently re-adopting the teachings of the state watch state. For this reason, it is necessary to first make changes to the Job Creation Law, especially the labor clusters by rearranging the principles in accordance to welfarestate concept by restoring and strengthening the function of the government as an element in industrial relations as a regulator and supervisor. Second, equalizing the position of workers/laborers so that they are equal to employers/entrepreneurs both juridically and sociologically, restoring a wage system that is in accordance with the consideration of the need for a decent life, guaranteeing the status of workers/laborers, ensuring the fulfillment of other rights, and to the government so that it is maximized. to carry out their duties and authorities in terms of supervision.

\section{References}

Abbas, Anwar. Bung Hatta dan Ekonomi Islam. Jakarta: Kompas Media Nusantara, 2010.

Alam, Syamsul., Mohammad Arif. "Perlindungan Hukum Terhadap Pekerja: Perspektif Tanggung Jawab Konstitusional Negara." Kalabbirang Law Journal 2, no. 2, 2020: 123-133.

Algra, Mr. N. E. Mula Hukum. Jakarta: Binacipta, 1983.

Amin, Rizal Irvan. "Omnibus Law Antara Desiderata Dan Realita." Jurnal Hukum Samudra Keadilan 15, no. 2, 2020: 190-209, DOI: 10.33059/jhsk.v15i2.2729.

Anggono, Bayu Dwi. "Omnibus Law Sebagai Teknik Pembentukan UndangUndang: Peluang Adopsi Dan Tantangannya Dalam Sistem Perundang-Undangan Indonesia." Jurnal RechtsVinding 9, no. 1 2020: 17-37.

Atmadja, I Dewa Gede. Ilmu Negara Sejarah. Konsep dan Kajian Kenegaraan. Malang: Setara Press, 2012.

Atmasasmita, Romli. Analisis Ekonomi Mikro Tentang Hukum Pidana Indonesia. Jakarta: Prenada Media, 2017. 
Azhar, Muhamad. "Omnibus Law sebagai Solusi Hiperregulasi Menuju Sonkronisasi Peraturan Per-Undang-undangan di Indonesia." Administrative Law and Governance Journal 2, no. 1, 2019: 170-178, DOI: 10.14710/alj.v2i1.170-178.

Barkatullah, Abdul Halim. "The Dialectics Of Freedom Of Contract Doctrine With Welfare-State Concept In Providing Legal Protection To Consumers." PalArch's Journal of Archaeology of Egypt/Egyptology 17, no. 6, 2020: 7248-7262.

Bogg, Alan. "'Individualism' and 'Collectivism'in Collective Labour Law." Industrial Law Journal 46, no. 1, 2017: 72-108, DOI: 10.1093/indlaw/dww045.

Chandranegara, Ibnu Sina., Syaiful Bakhri. "The Role of Political Ideology on Devolution of State Objectives." Tarumanagara Law Review 1, no. 1, 2019: 024-046, DOI: 10.24912/tlrev.v0i0.3055.

Charda, S. "Karakteristik Undang-Undang Ketenagakerjaan Dalam Perlindungan Hukum Terhadap Tenaga Kerja." Jurnal Wawasan Yuridika 32, no. 1, 2015: 1-21, DOI: 10.25072/jwy.v32i1.86.

Darmawan, Agus. "Politik Hukum Omnibus Law Dalam Konteks Pembangunan Ekonomi Indonesia." Indonesian Journal of Law and Policy Studies 1, no. 1, 2020: 13-24, DOI: 10.31000/ijlp.v1i1.2655.

Fitriana, Mia Kusuma. "Peranan Politik Hukum dalam Pembentukan Peraturan Perundang-Undangan di Indonesia sebagai Sarana Mewujudkan Tujuan Negara (Laws and Regulations In Indonesia As The Means Of Realizing The Country'S Goal)." Jurnal Legislasi Indonesia 12, no. 2, 2018: 1-27.

Hadiyono, Venatius. "Indonesia dalam Menjawab Konsep Negara Welfarestate dan Tantangannya." Jurnal Hukum, Politik dan Kekuasaan 1, no. 1, 2020: 23-33, DOI: 10.24167/jhpk.v1i1.2672.

Harahap, Arifuddin Muda. "Analisis Undang-undang Nomor 13 Tahun 2003 Tentang Ketenagakerjaan Di Tinjau dalam Kajian Politik Hukum." Jurnal Penelitian Medan Agama Jurnal Penelitian Medan Agama 10, no. 2, 2019: 281-297.

https://apple.co/3hXWJ0Lhttps://money.kompas.com/read/2020/10/06/1323 41526/diusulkan-jokowi-ini-perjalanan-panjang-keluarnya-uu-ciptakerja?page=all, accessed on December 30, 2020.

https://apple.co/3hXWJ0Lhttps://nasional.kompas.com/read/2020/11/03/000 85091/uu-cipta-kerja-resmi-dinomori-jadi-uu-nomor-11-tahun-2020, accessed on December 29, 2020.

https://jeo.kompas.com/naskah-lengkap-pidato-presiden-joko-widododalam-pelantikan-periode-2019-2024, accessed on December 23, 2020.

https://www.dpr.go.id/berita/detail/id/30590/t/UU+Ciptaker+Hadir+Untuk+I ndonesia+lebih+Maju, accessed on December 29, 2020. 
https://www-beta.kompas.id/baca/opini/2020/01/04/omnibus-law-uu-sapujagat/, accessed on January 3, 2021.

Ibrahim, Zulkainain. "Pengaturan dan Penegakan Hukum Pengupahan dalam Sistem Hukum Ketenagakerjaan." Ius Quia Iustum Law Journal of Islamic University of Indonesia 22, no. 4, 2015: 652-673.

Indika, Miki., Yayuk Marliza. "Upaya Upaya Pemberdayaan Usaha Mikro Kecil Menengah (UMKM) Dalam Mengatasi Kemiskinan di Kecamatan Tugumulyo Kabupaten Musi Rawas." Journal Management, Business, and Accounting 18, no. 3, 2019: 49-66, DOI: 10.33557/mbia.v18i3.598.

Ismiatun., Bunyamin Alamsyah. "Perlindungan Hukum Terhadap Pekerja Rumah Tangga Menurut Peraturan Menteri Ketenagakerjaan Nomor 2 Tahun 2015 Dalam Perspektif Hukum Positif Hukum Indonesia." Legalitas: Jurnal Hukum 9, no. 1, 2019: 113-142, DOI: 10.33087/legalitas.v9i1.144.

Mayasari, Ima. "Kebijakan Reformasi Regulasi Melalui Implementasi Omnibus Law Di Indonesia." Jurnal Rechts Vinding: Media Pembinaan Hukum Nasional 9, no. 1, 2020: 1-15, DOI: 10.33331/rechtsvinding.v9i1.401.

Muhammad, Abdulkadir. Hukum dan Penelitian Hukum. Bandung: Citra Aditya Bakti, 2014.

Nuradi. "Perlindungan Hukum Pekerja Alih Daya Dalam Pelaksanaan Hubungan Industrial Guna Mendukung Terwujudnya Iklim Investasi Yang Kondusif Bagi Tercapainya Kesejahteraan Pekerja." Pakuan Law Review 5, no. 1, 2019: 20-37, DOI: 10.33751/.v5i1.1184.

Palguna, I Dewa Gede. Walfare State Vs Globalisasi Gagasan Negara Kesejahteraan Di Indonesia. Depok: Rajawali Press, 2017.

Panjaitan, Saut P. "Politik Pembangunan Hukum di Bidang Investasi Suatu Keniscayaan Konstitusi Ekonomi." Jurnal Konstitusi 7, no. 2, 2016: 047-066, DOI: $10.31078 / \mathrm{jk} \% 25 x$.

Prabowo, Adhi Setyo., Andhika Nugraha Triputra, Yoyok Junaidi. "Politik Hukum Omnibus Law di Indonesia." Pamator Journal 13, no. 1, 2020: 1-6. DOI: 10.21107/pamator.v13i1.6923.

Ridlwan, Zulkarnain. "Negara Hukum Indonesia Kebalikan Nachtwachterstaat." FIAT JUSTISIA: Jurnal Ilmu Hukum 5, no. 2, 2014: 141-152.

Rohanawati, Ayunita Nur. "Jaminan Sosial Tenaga Kerja di Indonesia Sebagai Negara Kesejahteraan Ditinjau Dari Perspektif Hukum Progresif." Jurnal Ilmu Hukum Justitia Et Pax 32, no. 1, 2016: 17-31, DOI: 10.24002/jep.v32i1.759.

Setyawan, Yhannu. "Rancangan Undang-Undang Omnibus Law Cipta Kerja Dalam Perspektif Undang-Undang Nomor 12 Tahun 2011 Tentang 
Pembentukan Peraturan Perundang-Undangan." Jurnal Ilmiah Hukum dan Keadilan 7, no. 1, 2020: 150-164.

Sudiarawan, Kadek Agus, and Putu Ade Hariestha Martana. "Implikasi

Hukum Pengaturan Upah Minimum Sektoral Kabupaten Badung terhadap Pelaku Usaha pada Sektor Kepariwisataan di Kabupaten Badung Provinsi Bali." Supremasi Hukum: Jurnal Penelitian Hukum 28, no. 1, 2019: 35-56, DOI: 10.33369/jsh.28.1.33-56.

Susmiyati, Haris Retno., Erna Susanti. "Implementasi Kewajiban Mempekerjakan Tenaga Kerja Lokal Pada Perusahaan Pertambangan Batubara Di Kabupaten Berau Kalimantan Timur." Risalah Hukum 15, no. 1, 2019: 11-31.

Theddy. "Pembaruan Hukum dalam Perlindungan Hukum terhadap Pekerja/Buruh di Indonesia dalam Mewujudkan Kesejahteraan." Warta Dharmawangsa 14, no. 3, 2020: 379-381.

Triwahyuningsih, Susani. "Perlindungan dan Penegakan Hak Asasi Manusia (HAM) di Indonesia." Legal Standing: Jurnal Ilmu Hukum 2, no. 2, 2018: 113-121, DOI: 10.24269/ls.v2i2.1242.

Wibowo, Suyanto Edi. "Memahami Makna Pasal 33 Undang-Undang Dasar Negara Republik Indonesia Tahun 1945 Perihal Penguasaan Oleh Negara Terhadap Sumber Daya Alam Comprehend." Jurnal Legislasi Indonesia 12, no. 4, 2018: 1-57 .

Zulkarnaen, Ahmad Hunaeni. "Masalah Rawan Dalam Hubungan Industrial Dan Konsep Negara Kesejahteraan Indonesia." Jurnal Hukum Mimbar Justitia 2, no. 2, 2018: 806-825, DOI: 10.35194/jhmj.v2i2.32.

Zulkarnaen, Ahmad Hunaeni."Perlindungan Hukum Terhadap Pekerja Dalam Pelaksanaan Hubungan Industrial." Padjadjaran Journal of Law 3, no. 2, 2016: 407-427, DOI: 10.22304/pjih.v3n2.a10. 